\title{
Optimization of Chemical Pretreatment for Osmotic Dehydrated Talaja Red Onion Slices Using Response Surface Methodology
}

\author{
Deven Ashok Rane and Mukesh N. Dabhi \\ ${ }^{1}$ Research Scholar, Department of Processing and Food Engineering, College of Agril. Engg. \& Technology, \\ Junagadh Agricultural University, Junagadh \\ ${ }^{2}$ Research Engineer AICRP on Post Harvest Engineering and Technology, Department of Processing and Food \\ Engineering, College of Agril. Engg. \& Technology, JAU, Junagadh \\ Email:mndabhi@jau.in
}

\begin{abstract}
Onion is an important vegetable crop throughout the world. Its storage is difficult hence, it is dehydrated for value addition. Osmotic dehydration is one of the options for dehydration of onion. The effect of chemical pretreatments to onion slices using calcium chloride $(\mathrm{CaCl} 2)$ and potassium metabisulphite (KMS) prior to osmotic dehydration was examined by dipping the onion slices in the respective chemical solution. Optimization of chemical pretreatments prior to osmotic dehydration of onion slices was carried out using RSM. CaCl2 concentration had significant effect at $5 \%$ level on water loss. Pretreatment combination of $3.00 \% \mathrm{CaCl} 2$ and $0.20 \% \mathrm{KMS}$ concentration resulted maximum water loss $(43.07 \%)$ while, Pretreatment combination of $1.00 \% \mathrm{CaCl} 2$ and $0.20 \%$ KMS concentration resulted minimum solid gain. Similarly, maximum weight loss (37.94\%) was found for pretreatment combination of $2.00 \% \mathrm{CaCl} 2$ concentration and $0.30 \% \mathrm{KMS}$ concentration and minimum moisture content $(48.89 \%)$ was found in pretreatment combination of $2.00 \% \mathrm{CaCl} 2$ and $0.30 \%$ KMS. The chemical pretreatment prior to osmotic dehydration of Talaja Red onion slices was optimized with combination of $3.00 \% \mathrm{CaCl} 2$ and $0.15 \%$ KMS.
\end{abstract}

Keywords: Pretreatment, osmotic dehydration, $\mathrm{CaCl} 2$, KMS.

\section{Introduction}

Onion (Allium cepa L.) is an important spice and vegetable crop grown all over world. India is the second largest producer of onion, in the world next only to China but the productivity of onion in India is very low as compared to China and other countries like, Egypt, Netherlands, \& Iran etc [2]. Potato $(28.9 \%)$, tomato $(11.3 \%)$, onion $(10.3 \%)$, and Brinjal $(8.1 \%)$ are the four major vegetables contributing $58.6 \%$ of total vegetable production in India [2]. The production of onion in India during the year 20132014 was 194.02 lakhs metric ton from the 12.04 lakh hectare land with productivity of 16.12 ton/ha [14]. Indian onions have two crop cycles, the first harvesting starts from November to January and the second harvesting from January to May. The onion is more perishable and cannot be kept more time due to its perishable nature. The requirement of onion is almost constant throughout the year and availability of fresh onion is limited to 7 or 8 months and there are lean periods when prices shoot up because of poor storage conditions available in the country. There are Onion (Allium cepa L.) that is an extremely important vegetable crop not only for internal consumption for India but also as the highest foreign exchange earner among the fruits and vegetables through export. Indian onions are famous for their pungency and are available round the year. There is a lot of demand of Indian Onion in the world, India has exported 14.83 lakh MT with a value of Rs. 3169.61 crores during the year 2013-2014 [2]. About $40-50 \%$ post harvest losses are observed of onion during storage, transportation, and marketing [3].

Onions are a nutrient-dense food, meaning that while they are low in calories they are high in beneficial nutrients like vitamins, minerals, and antioxidants. Onions are also a source of the strong antioxidant vitamin $\mathrm{C}$ that helps to combat the formation of free radicals known to cause cancer [15].

Dehydrated bulb or onion powder is in great demand which reduces transportation cost and storage losses. Dried onion flakes can be reconstituted by cooking in water. Osmotic dehydration preceding air 
drying decreases colour changes and increases flavor retention in dried fruits and vegetables [17]. The resulting product has generally better quality than the dried one without pretreatment. Improvement of hot air drying process is essential if further growth of the onion dehydration industry is envisaged. As bulk of onion is water (82-87\%), reduction of moisture using suitable mechanical means prior to conventional hot air drying can be a simple technique to reduce moisture loading on dryer and hence the energy consumption. Also it is a well-known fact that each $1 \%$ reduction in feed moisture leads to $4 \%$ less dryer energy input [5][21]. Effect of mechanical dewatering prior to hot air drying was investigated on drying time, specific energy consumption, flavour, and colour of dried product [12]. Osmotic dehydration is a method for the partial dehydration of water-rich foods, such as fruits and vegetables, by immersing them in a concentrate solution of sugar or salt. It results in two simultaneous crossed flows: a water outflow, from the food to the solution and a solute outflow, from the food to the solution and a solute inflow from the solution into the food [13][31]. Water loss and solute gain are usually measured as average values in the piece of food. There are a few papers published about the concentration profiles developed in structured foods during osmotic dehydration [13][31][27]. There is information about the concentration profiles developed during osmotic dehydration of apple tissue [27]. The product thus loses water and gains solid from the external solution. Therefore, it is being widely used to reduce the water content of many fruits and vegetables [19]. For achieving high yield of final product, the kinetics of solid gain is more important than that of water loss. Kinetics of water loss in osmotic dehydration has been extensively studied for many fruits, including blueberries [9][30]. The quality traits and nutritional value of osmo dried fruits and vegetables can be modified depending on the parameters of the dehydration process and osmotic agent used [20][6]. The dehydrated material becomes impregnated with osmotic agent that not only enhances its sensory properties, but also has an impact on its dietary value [33].

Pretreatment is an essential step in the processing of food materials [28]. Various methods of pretreatment, which reduce drying time include chemical pretreatment, blanching, and osmotic dehydration [1][25][32][34]. Many researchers reported that pretreatment can speed up drying rate, improve the quality of dried product, prevent browning, and help retain volatile compounds [16][29]. Researchers (such as Xiao et al., 2009: Davoodi et al., 2007; Gazanfer \& Sefa, 2006, and Doymaz, 2004) $[8][10][11][[35]$ showed that chemical pretreatment could significantly accelerate the drying process and remarkably improve the quality of dried products such as sweet potatoes, mushrooms, red pepper, and plums. Pretreatment prior to osmotic dehydration is desirable to accelerate the dewatering process. Yadav and Singh (2014) reported the effect of pretreatment to increase the osmotic process in fruits and vegetables [36]. Phissut et al. (2013) reported the fast osmotic dehydration of cantaloupe due to effect of pretreatments of $\mathrm{CaCl} 2[24]$.

Talaja Red onion of Sauratshtra Region of Gujarat has higher value for exporting as a row and dehydrated product in Middle East countries. There are about hundreds of dehydrated industry cluster in this region. This study is limited to investigation regarding effect of pretreatment on different parameter such as water loss, solid gain, weight loss and moisture content for the effectiveness of osmotic dehydration of Talaja Red onion so that optimization technique could be used at a later stage for developing shelf-stable products.

\section{$2 \quad$ Materials and Methods}

The freshly harvested and matured onions of Talaja red variety were procured from the APMC market, Mahuva. The outer skin of onion bulbs was removed with the help of stainless steel knife. The peeled onion bulbs were thoroughly washed with fresh water to remove adhered earth and foreign materials. Finally they were dried in the shade for one hour to remove the surface water. The onion bulbs were sliced to $4 \mathrm{~mm}$ thickness by using stainless steel knife.

The experiment mainly consists of experimental design, preparation of chemical solution, chemical pretreatments and osmotic dehydration process.

\section{Experimental design}

The Design Expert 8.0.7.1 software was used in making the experimental design for chemical pretreatment prior to osmotic dehydration of onion slices. Response Surface Methodology (RSM) was 
used for designing the experiments. The quadratic model of Central Composite Design (CCD) was selected for making experimental design [7].

The effect of two independent variables viz. calcium chloride $(\mathrm{CaCl} 2)$ concentration and Potassium metabisulphite (KMS) concentration on water loss, solid gain, and weight loss were studied with variables coded as X1 and X2 respectively. The ranges of parameter values were carefully chosen based on the literature available on the chemical pretreatments of vegetables prior to drying. The ranges and levels of the parameters are shown in Table 1.

Table 1. Code and actual values of different variables for experimentation

\begin{tabular}{l|l|l|l|l|l}
\hline Variables $\backslash$ Code & -2 & -1 & 0 & +1 & +2 \\
\hline $\mathrm{CaCl} 2$ concentration, \% & 1.00 & 1.29 & 2.00 & 2.70 & 3.00 \\
\hline KMS concentration, \% & 0.10 & 0.12 & 0.20 & 0.27 & 0.30 \\
\hline
\end{tabular}

Process parameters (Factors i.e., two of five levels)

$\mathrm{CaCl} 2$ concentration (X1): 1.00, 1.29, 2.00, 2.70, and 3.00\%

KMS concentration (X2): $0.10,0.12,0.20,0.27$, and $0.30 \%$

Total number of treatment combinations (Runs)

$$
\begin{aligned}
\text { Totalno.of treatments combinations }= & {[\text { No.of replications } x(2) \text { No.of variables }] . } \\
& +[\text { No.of replications } x(2 x \text { No.of variables })] . \\
& + \text { center points }+ \text { Control } \\
& =(1 x 2 x 2)+(1 x 2 x 2)+5+1=14
\end{aligned}
$$

Table 2. Experimental combinations for chemical pretreatment of onion slices

\begin{tabular}{l|l|l}
\hline Exp. Run & $\mathrm{CaCl} 2 \%$ & KMS\% \\
\hline 1 & 2.00 & 0.20 \\
\hline 2 & 2.00 & 0.20 \\
\hline 3 & 2.70 & 0.13 \\
\hline 4 & 2.00 & 0.20 \\
\hline 5 & 2.70 & 0.27 \\
\hline 6 & 2.00 & 0.20 \\
\hline 7 & 2.00 & 0.20 \\
\hline 8 & 1.29 & 0.13 \\
\hline 9 & 2.00 & 0.10 \\
\hline 10 & 2.00 & 0.30 \\
\hline 11 & 1.00 & 0.20 \\
\hline 12 & 3.00 & 0.20 \\
\hline 13 & 1.29 & 0.27 \\
\hline 14 & Control $(0.00)$ & Control $(0.00)$ \\
\hline
\end{tabular}

\subsection{Evaluation of Chemical Pretreatment Characteristics}

Chemical pretreatment characteristics of onion slices were evaluated on the basis of solid gain, water loss, weight loss, and moisture content. The solid gain (SG) is the net uptake of solids by the onion slices. The water loss (WL) is the net loss of water from the product on initial mass basis. The weight loss is the net weight loss of the onion slice on initial weight basis. The solid gain, water loss and weight loss was calculated using the equations suggested by Islam and Flink (1982).

$$
S G=\frac{W_{\theta}\left(1-X_{\theta}\right)-W_{i}(1-X)}{W_{i}} x 100
$$




$$
\begin{gathered}
W L=\frac{W_{i} X_{i}-W_{\theta} X_{\theta}}{W_{i}} x 100 \\
\text { WeightLoss }=\frac{W_{i}-W_{\theta}}{W_{i}} x 100
\end{gathered}
$$

where,

$\mathrm{SG}=$ Solid gain (g/100g initial mass of slices)

$\mathrm{WL}=$ Water loss $(\mathrm{g} / 100 \mathrm{~g}$ initial mass of slices $)$

$\mathrm{W} \theta=$ Mass of slices after duration $\theta, \mathrm{g}$

$\mathrm{X} \theta=$ Water content as a fraction of mass of slices at duration $\theta, \mathrm{g}$

$\mathrm{Wi}=$ Initial mass of slices, $\mathrm{g}$

$\mathrm{Xi}=$ Water content as a fraction of initial mass of slices.

\subsection{Moisture Content}

The moisture content of fresh as well as osmotically dehydrated onion samples was determined by using air oven method and calculated by using the following equation.

$$
\text { Percent moisture content }(d b) \frac{W_{1}-W_{2}}{W_{1}}=100
$$

\subsection{Preparation of Chemical Solution}

The chemical pretreatment on onion slices was carried out with mixed solutions of calcium chloride $(\mathrm{CaCl} 2)$ and potassium metabisulphite (KMS). Mixed solutions were prepared by mixing appropriate amount of calcium chloride $(\mathrm{CaCl} 2)$ and potassium metasuplhite (KMS) in distilled water on percentage basis.

\subsection{Chemical Pretreatments}

The effect of chemical pretreatments to onion slices using calcium chloride $(\mathrm{CaCl} 2)$ and potassium metabisulphite (KMS) prior to osmotic dehydration was examined by dipping the onion slices (4 mm thick) in the respective chemical solution for 10 minutes as suggested by Mozumder et al. (2012) [23].

\subsection{Data Analysis and Optimization}

The CCD design was used to conduct experiment and the Response Surface Methodology (RSM) was applied to the experimental data using a commercial statistical package, Design Expert-version 8.0.7.1 (Stat-ease, 21012). Analysis of variance (ANOVA) was conducted for fitting the model represented by equation 1 to examine the statistical significance of the model terms. Model analysis with respect to lack-of-fit test and R2 (coefficient of determination) was done for determining adequacy of model. The coefficient of variance $(\mathrm{CV})$ was calculated to find the relative dispersion of the experimental points from the prediction of the model. Response surfaces were generated and by using the same software, numerical optimization was done. The most commonly used model for optimization using response surface methodology is a second order polynomial equation (5) [4]. The model is of the form,

$$
Y_{k}=b_{k 0}+\sum_{i=1}^{4} b_{k i} X_{i}+\sum_{i=1}^{4} b_{k i i} X_{i}^{2}+\sum_{i \neq j=1}^{4} b_{k i j} X_{i} X_{j}
$$

$(\mathrm{k}=0,1,2,3 \ldots)$

where $\mathrm{Yk}$ is the response, bk0, bki, bkii, and bkij, are the constant, linear, quadratic, and corss-product regression coefficients respectively and Xi's are the coded independent variables. Numerical optimization technique of the Design-Expert software was used for simultaneous optimization of the multiple responses. The desired goals for each factor and responses were chosen. The goals may apply to either factors or responses. The possible goals are maximize, minimize, target, within range, none (for responses only), and set to an exact value (for factors only). In order to search a solution maximizing 
multiple responses, the goals were combined into an overall composite function, $\mathrm{D}(\mathrm{x})$, called the desirability function [22], which is defined as,

$$
D(x)=(Y 1 x Y 2 x \ldots x Y n)^{1 / n}
$$

where,

Yi $(\mathrm{i}=1,2, \ldots \mathrm{n})$ are the responses and $\mathrm{n}$ is the total number of responses in the measure.

The optimized solution parameters were used for further study i.e., to examine effect of chemical pretreatment on osmotic dehydration of onion slices.

\subsection{Osmotic Dehydration Process}

After the chemical pretreatments, osmotic dehydration was carried out at the optimized conditions of process parameter and osmotic solution concentrations. For the osmotic dehydration of chemically pretreated onion slices were osmotically dehydrated with optimized parameters i.e. process temperature $42.08{ }^{\circ} \mathrm{C}$, immersion time $111.13 \mathrm{~min}$, salt concentration $8.03 \%$ and sugar concentration $55 \%$.

The optimized solution was used for further study i.e., tray drying of chemically pretreated onion slices at optimized osmotic dehydration conditions.

\section{$3 \quad$ Results and Discussions}

Prior to study the effect of pretreatment on osmotic dehydration, solution parameters for osmotic dehydration process were optimized. A best combination of calcium chloride and potassium metabisulphite was selected with respect to maximum water loss, minimum solid gain, maximum weight loss, and minimum moisture content

The analysis of variance (ANOVA) (Table 4) was conducted on experimental data and the significance of concentration of calcium chloride and potassium metabisuphite as well as their interactions on water loss, solid gain, weight loss, and moisture content were calculated. The quadratic model was fitted to the experimental data and statistical significance of linear, quadratic and interaction effects were calculated for each response and are given in Table 3.

Table 3. Effect of chemical pretreatments prior to osmotic dehydration on water loss, solid gain, weight loss and moisture content of onion slices.

\begin{tabular}{l|l|l|l|l|l|l}
\hline \multirow{2}{*}{ Exp. No. } & \multicolumn{2}{l}{ Variables (Actual values) } & \multicolumn{4}{l}{ Responses } \\
\cline { 2 - 7 } & $\begin{array}{l}\text { A: CaCl2 } \\
\text { Conc. } \%\end{array}$ & $\begin{array}{l}\text { B: KMS } \\
\text { Conc. } \%\end{array}$ & $\begin{array}{l}\text { Water } \\
\text { loss, } \%\end{array}$ & $\begin{array}{l}\text { Solid } \\
\text { gain, } \%\end{array}$ & $\begin{array}{l}\text { Weight } \\
\text { loss, \% }\end{array}$ & $\begin{array}{l}\text { Moisture } \\
\text { content, } \%\end{array}$ \\
\hline 1 & 2.00 & 0.20 & 39.95 & 5.76 & 34.19 & 52.88 \\
\hline 2 & 2.00 & 0.20 & 42.89 & 5.76 & 37.13 & 55.42 \\
\hline 3 & 2.70 & 0.13 & 41.67 & 5.57 & 36.10 & 51.08 \\
\hline 4 & 2.00 & 0.20 & 40.87 & 5.49 & 35.38 & 54.17 \\
\hline 5 & 2.70 & 0.27 & 41.93 & 6.07 & 35.86 & 52.18 \\
\hline 6 & 2.00 & 0.20 & 41.33 & 5.21 & 36.12 & 55.64 \\
\hline 7 & 2.00 & 0.20 & 43.03 & 5.09 & 37.94 & 54.46 \\
\hline 8 & 1.29 & 0.13 & 39.12 & 5.87 & 33.25 & 51.70 \\
\hline 10 & 2.00 & 0.10 & 40.24 & 5.67 & 34.57 & 54.95 \\
\hline 11 & 2.00 & 0.30 & 41.44 & 5.92 & 35.52 & 48.89 \\
\hline 12 & 1.00 & 0.20 & 38.88 & 4.98 & 33.90 & 53.52 \\
\hline 13 & 3.00 & 0.20 & 43.07 & 5.22 & 37.85 & 49.90 \\
\hline 14 & 1.29 & 0.27 & 39.67 & 5.33 & 34.34 & 53.92 \\
\hline Control) & 0.00 & 0.00 & 41.09 & 6.05 & 35.04 & 53.61 \\
\hline
\end{tabular}




\subsection{Effect of Chemical Pretreatments on Water Loss}

The results showed that among the linear effects, only $\mathrm{CaCl} 2$ concentration had significant effect at $5 \%$ level of significance on water loss while all the other linear, interaction, and quadratic effects of $\mathrm{CaCl} 2$ and KMS concentration were found to be non-significant on water loss, solid gain, water loss, and moisture content. All the four model values were non-significant.

The interaction effect of $\mathrm{CaCl} 2$ concentration and KMS concentration (Fig. 1) reveals that at lower KMS concentration water loss was found to be the function of $\mathrm{CaCl} 2$ concentration and increased with the increase of $\mathrm{CaCl} 2$ concentration. At higher $\mathrm{KMS}$ concentration, water loss increased with $\mathrm{CaCl} 2$ concentration and then decreased with further increase of $\mathrm{CaCl} 2$ concentration. The maximum water loss $43.07 \%$ obtained with $3 \% \mathrm{CaCl} 2$ concentration and $0.20 \%$ of KMS concentration while minimum water loss of $38.88 \%$ at $1.00 \% \mathrm{CaCl} 2$ concentration and $0.20 \%$ of KMS concentration. The combine effect shows negative approach. Results were supported by Davoodi et al., Dermesonlouoglou et al., [8] [9]. The final equation for water loss in terms of actual factors is as follows,

$$
\text { Waterloss }(\%)=41.61+1.34 A+0.31 B-0.073 A B-0.40 A^{2}-0.46 B^{2}
$$

where, $\mathrm{A}=\mathrm{CaCl} 2$ concentration (\%), $\mathrm{B}=\mathrm{KMS}$ concentration (\%)
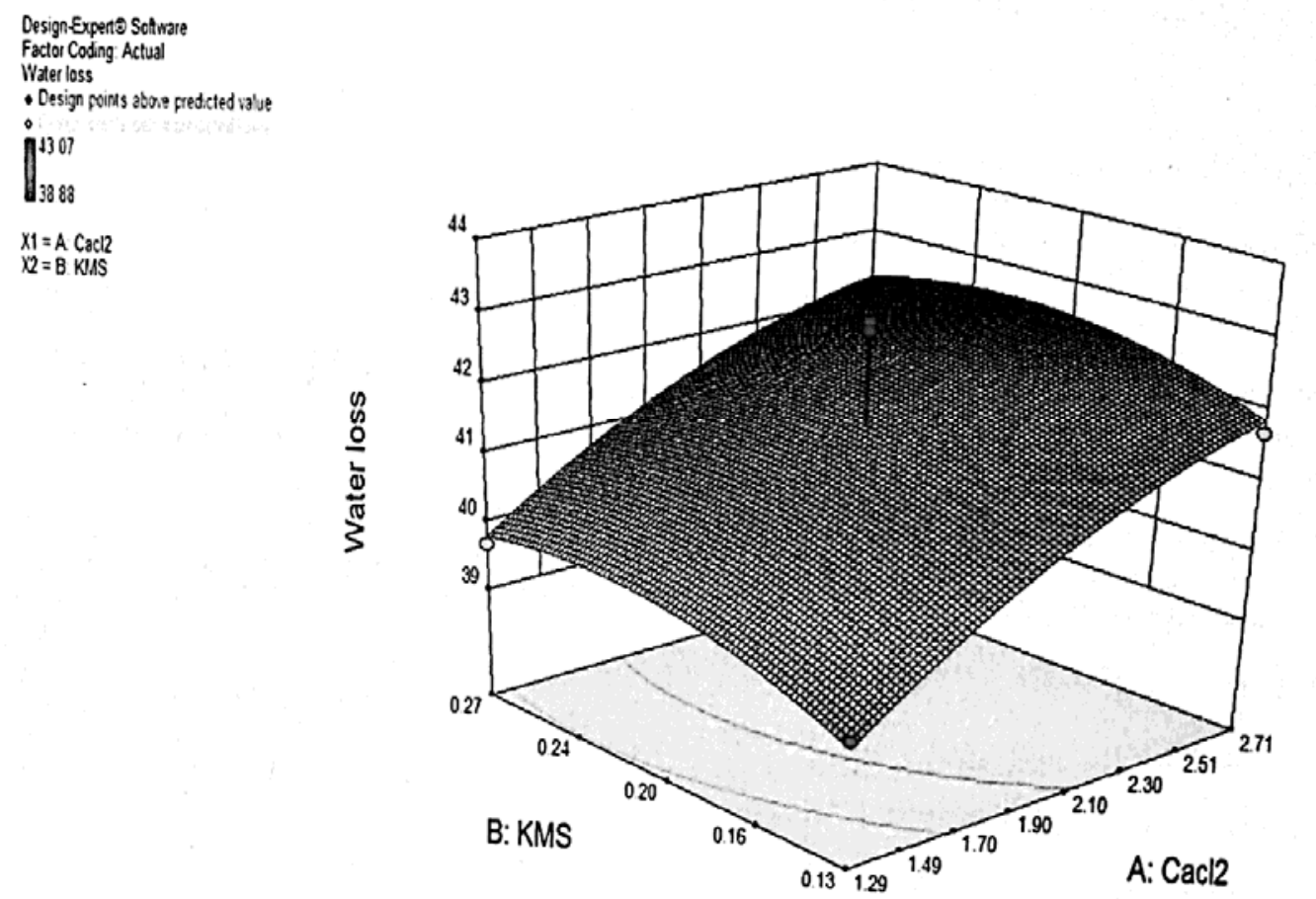

Figure 1. Response surface of water loss as a function of $\mathrm{CaCl} 2$ and $\mathrm{KMS}$ concentration

\subsection{Effect of Chemical Pretreatments on Solid Gain}

Fig. 2 depicts the response surface plot for effect of $\mathrm{CaCl} 2$ concentration and KMS concentration on solid gain. Solid gain decreased with $\mathrm{CaCl} 2$ and KMS concentration upto some level as well as combined effect shows positive approach (eq. 4).

The minimum solid gain (4.98) was found in treatment combination of $1.00 \% \mathrm{CaCl} 2$ concentration and $0.20 \%$ KMS concentration, while the maximum solid gain (6.07) was found in treatment combination of $2.71 \% \mathrm{CaCl} 2$ concentration and $0.27 \%$ KMS concentration (Table 3). Results were according to Doymaz, as well as Gazenfer E and Sefa [10][11]. The model F-value of 0.15 implies that the model is not significant. R2 and CV\% values for solid gain were 0.61 and $5.01 \%$ respectively which 
indicated that the model could fit the data for solid gain very well for both variables, i.e., $\mathrm{CaCl} 2$ and KMS concentration.

The response surface equation of second order obtained in terms of coded factors to predict the variation in solid gain during chemical pretreatment prior to osmotic dehydration of onion slices with varying levels of processing parameters is as follows,

Solid gain $(\%)=5.46+0.097 \mathrm{~A}+0.039 \mathrm{~B}+0.26 \mathrm{AB}-0.12 \mathrm{~A}^{2}-0.23 \mathrm{~B}^{2}$

where, $\mathrm{A}=\mathrm{CaCl} 2$ concentration (\%), $\mathrm{B}=\mathrm{KMS}$ concentration (\%)
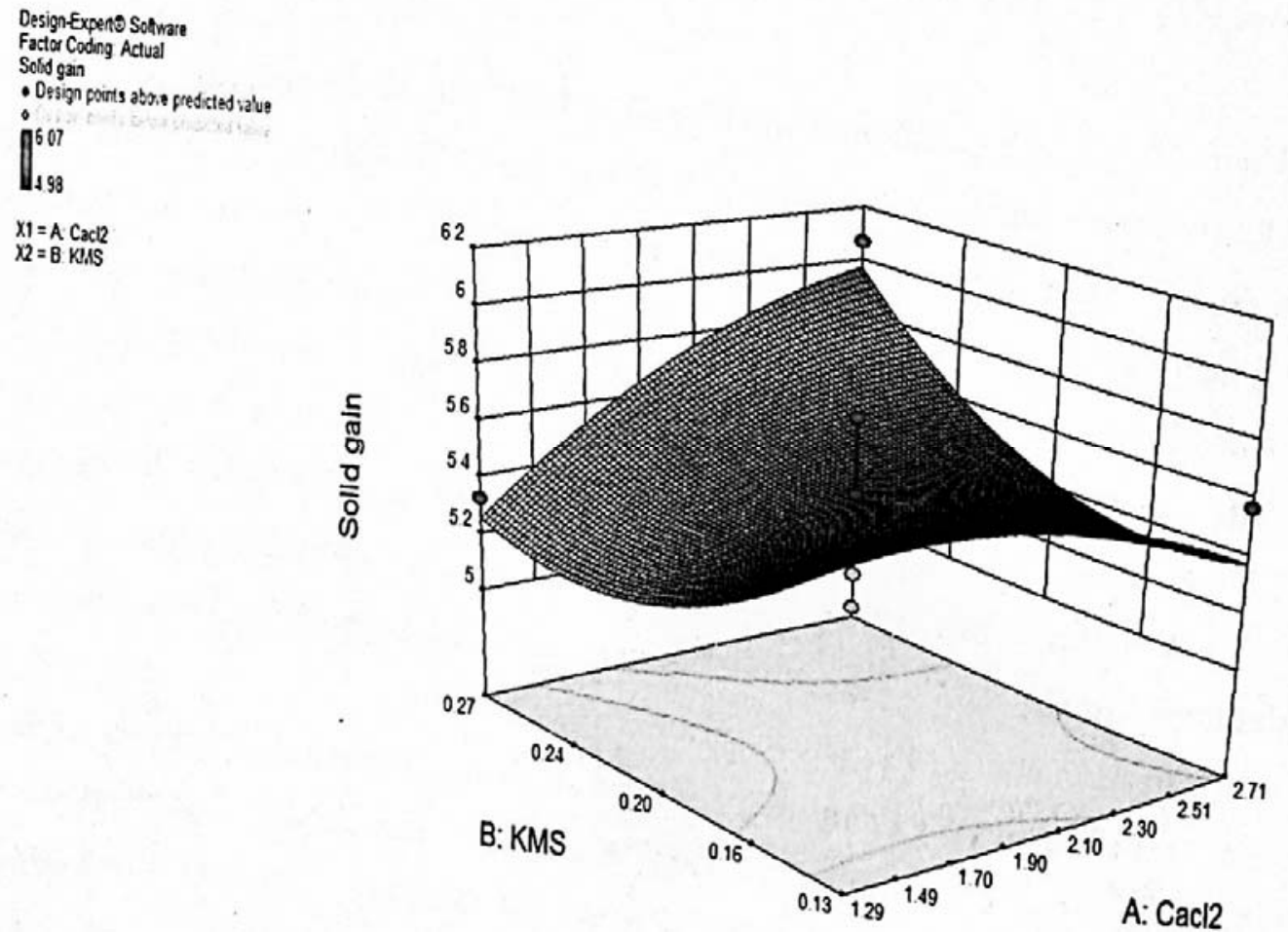

Figure 2. Response surface of solid gain as a function of $\mathrm{CaCl} 2$ and KMS concentration

\subsection{Effect of Chemical Pretreatments on Weight Loss}

The interaction effect of $\mathrm{CaCl} 2$ and KMS concentration (Fig 3) shows that at lower KMS concentration, weight loss was found to be the function of $\mathrm{CaCl} 2$ concentration and it increased with $\mathrm{CaCl} 2$ concentration. At higher KMS concentration weight loss initially increased with KMS concentration and then decreased with further increase in $\mathrm{CaCl} 2$ concentration. The maximum weight loss (37.94\%) was found in treatment combination of $2.00 \% \mathrm{CaCl} 2$ and $0.20 \% \mathrm{KMS}$ concentration, while the minimum weight loss $(33.25 \%)$ was found in treatment combination of $1.29 \% \mathrm{CaCl} 2$ and $0.13 \%$ KMS concentration (Table 3). Results were in accordance with Lewicki, Mozumeder [18] [23]

The model F-value of 0.23 implies that the model is not significant. R2 and CV \% values for weight loss were 0.56 and $5.74 \%$ respectively which indicated that the model could fit the data for weight loss very well for both the variables, i.e., $\mathrm{CaCl} 2$ and $\mathrm{KMS}$ concentration.

The regression equations describing the effects of pretreatment prior to osmotic dehydration of onion slices in terms of actual levels of variables are given as,

Weight $\operatorname{loss}(\%)=34.59+0.99 \mathrm{~A}+0.73 \mathrm{~B}+0.065 \mathrm{AB}+1.69 \mathrm{~A}^{2}-1.22 \mathrm{~B}^{2}$

where, $\mathrm{A}=\mathrm{CaCl} 2$ concentration (\%), $\mathrm{B}=\mathrm{KMS}$ concentration (\%) 


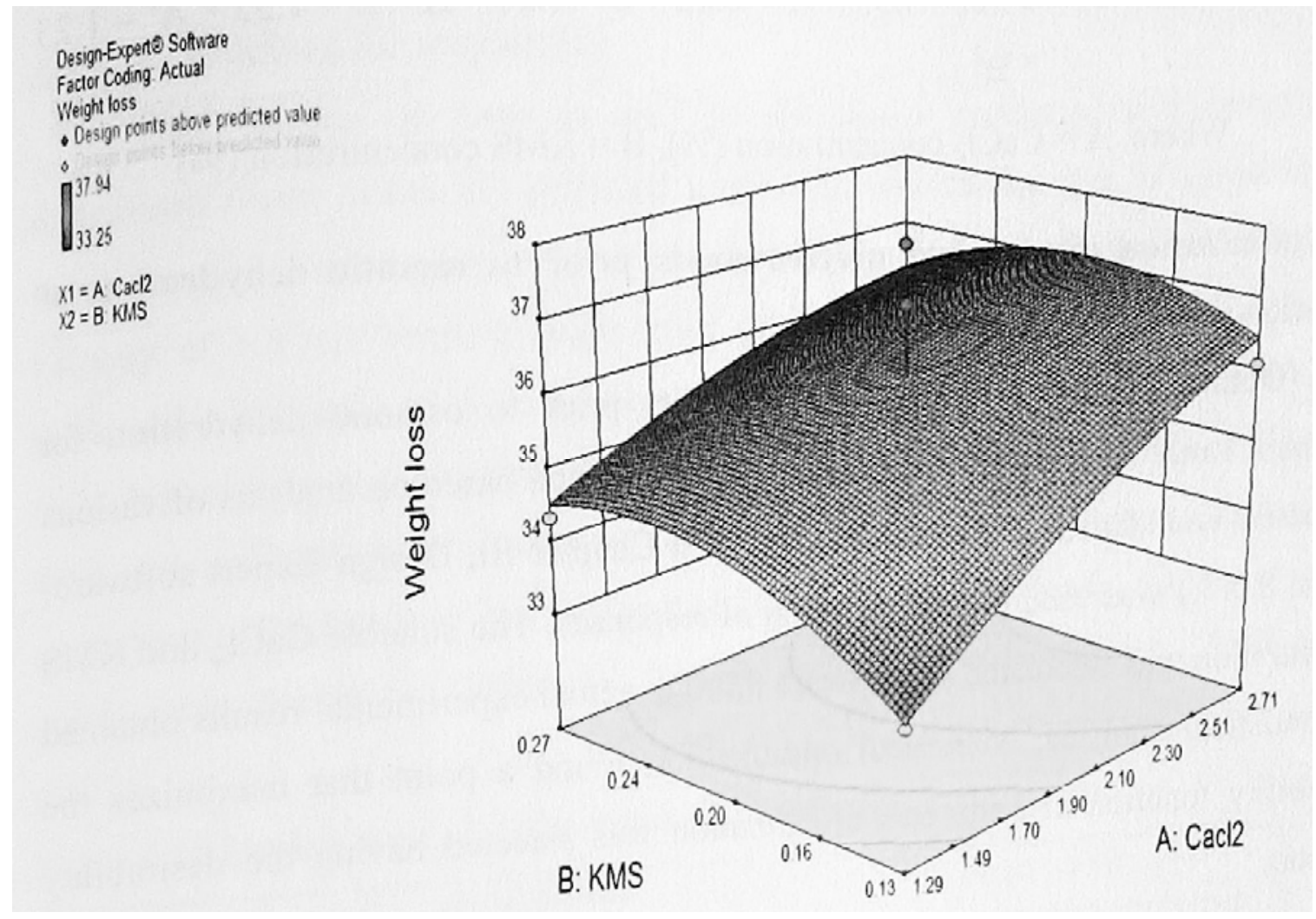

Figure 3. Response surface of water as a function of $\mathrm{CaCl} 2$ and KMS concentration

\subsection{Effect of Chemical Pretreatments on Moisture Content}

The effect of independent variables on the moisture content of onion slices is shown in Fig. 4. The moisture content of onion slice was influenced by quadratic effect of $\mathrm{CaCl} 2$ and $\mathrm{KMS}$ concentration. The moisture content varied from 48.89 to $55.64 \%$ (Table 3). The maximum moisture content (55.64\%) was found in treatment combination $2.00 \% \mathrm{CaCl} 2$ and $0.20 \% \mathrm{KMS}$ concentration, while the minimum moisture content (48.89\%) was found in treatment number 10 having the combination of $2.00 \% \mathrm{CaCl} 2$ and $0.30 \%$ KMS concentration. It was in accordance with Phissut [24] for the cantaloupe product.

The model F-value of 0.22 implies that the model is not significant. R2 and CV\% values for moisture content were 0.57 and $3.47 \%$ respectively which indicated that the model could fit the data for moisture content very well for both the variables, i.e., $\mathrm{CaCl} 2$ concentration and KMS concentration.

The final equation for moisture content in terms of actual factors is as follows,

Moisture content $(\%)=54.63-0.93 \mathrm{~A}+0.66 \mathrm{~B}-0.28 \mathrm{AB}-1.35 \mathrm{~A}^{2}-1.25 \mathrm{~B}^{2}$

where, $\mathrm{A}=\mathrm{CaCl} 2$ concentration (\%), $\mathrm{B}=\mathrm{KMS}$ concentration (\%) 


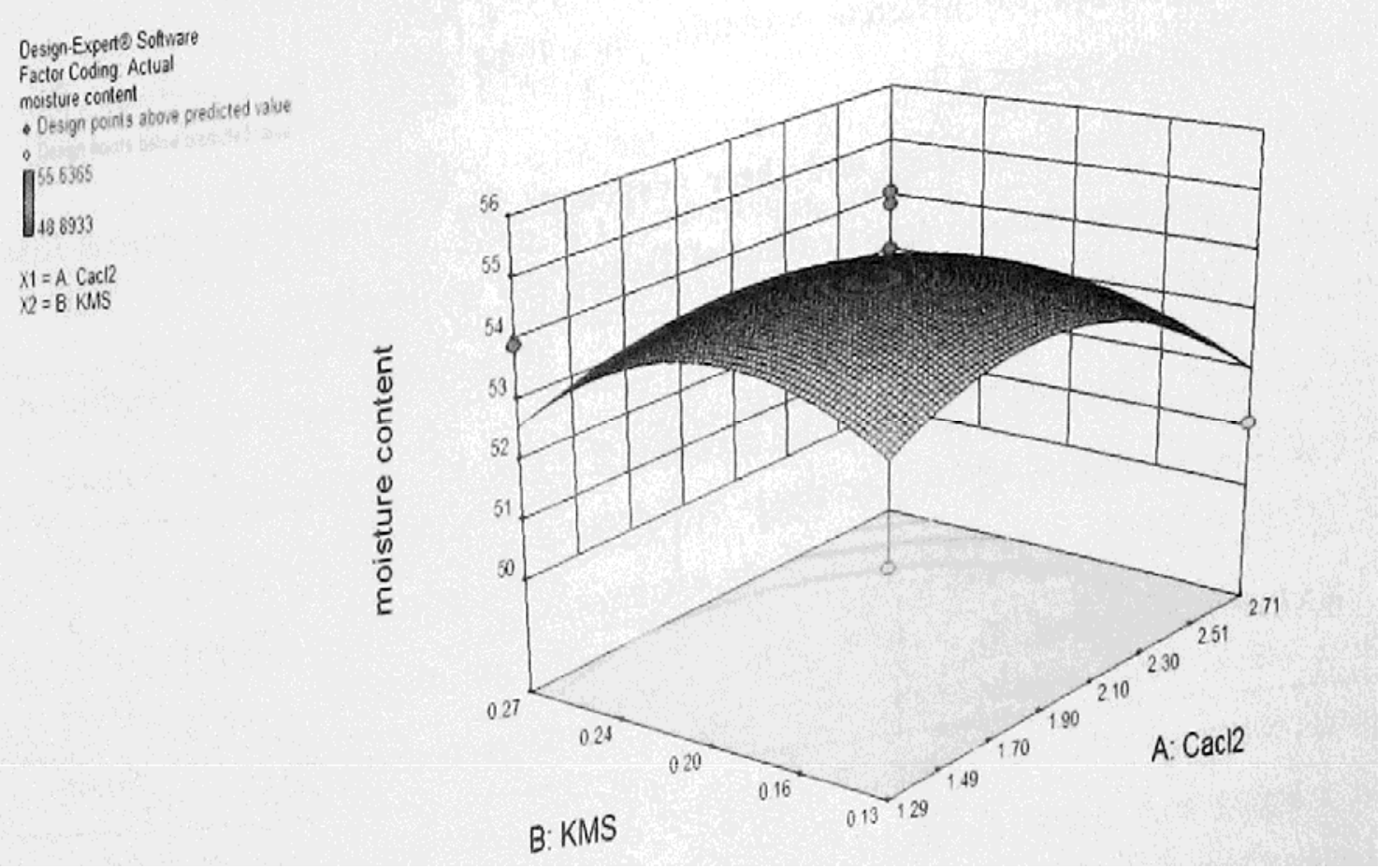

Figure 4. Effect of $\mathrm{CaCl} 2$ and $\mathrm{KMS}$ concentration on moisture content

Table 4. Analysis of variance

\begin{tabular}{|c|c|c|c|c|c|c|c|c|c|c|c|c|c|c|c|c|c|}
\hline Sour & df & SS & MS & $\begin{array}{l}\text { F } \\
\text { value }\end{array}$ & $\begin{array}{l}\mathrm{p}- \\
\text { value }\end{array}$ & SS & MS & \begin{tabular}{|l|}
$\mathrm{F}$ \\
value
\end{tabular} & $\begin{array}{l}\mathrm{p}- \\
\text { value }\end{array}$ & SS & MS & $\begin{array}{l}\text { F } \\
\text { value }\end{array}$ & $\begin{array}{l}\mathrm{p}- \\
\text { value }\end{array}$ & SS & MS & \begin{tabular}{|l|}
$\mathrm{F}$ \\
value
\end{tabular} & $\begin{array}{l}\mathrm{p}- \\
\text { value }\end{array}$ \\
\hline & & \multicolumn{4}{|c|}{ Water loss, $\%$} & \multicolumn{4}{|c|}{ Solid gain, \% } & \multicolumn{4}{|c|}{ Weight loss, $\%$} & \multicolumn{4}{|c|}{ Moisture content, $\%$} \\
\hline del & 5 & 17.52 & 3.50 & 3.28 & 0.0767 & 0.88 & 0.18 & 2.30 & 0.1543 & 38.89 & 7.78 & 1.78 & 0.2349 & 31.66 & 6.33 & 1.88 & 0.2172 \\
\hline vats & 1 & 14.41 & 14.41 & $13.48^{*}$ & 0.0080 & 0.076 & 0.076 & 0.99 & 0.3536 & 7.80 & 7.80 & 1.79 & 0.2229 & 6.98 & 6.98 & 2.07 & 0.1936 \\
\hline $\mathrm{KN}$ & 1 & 0.79 & 0.79 & 0.74 & 0.4196 & 0.012 & 0.012 & 0.16 & 0.7014 & 4.21 & 4.21 & 0.96 & 0.3587 & 3.47 & 3.47 & 1.03 & 0.3446 \\
\hline $\mathrm{AB}$ & 1 & 0.02 & 0.02 & 0.02 & 0.8924 & 0.27 & 0.27 & 3.51 & 0.1030 & 0.017 & 0.017 & 0.004 & 0.9521 & 0.31 & 0.31 & 0.09 & 0.7695 \\
\hline $\mathrm{A} 2$ & 1 & 10 & 1.10 & 1.03 & 3449 & 0.093 & 0.093 & 1.20 & 0.3 & 19.80 & 19.80 & 4.54 & 0.0706 & 12.74 & 12.74 & 3.77 & 0.0932 \\
\hline$=$ & 1 & 1.50 & 1.50 & 1.40 & 0.2747 & 0.37 & 0.37 & 4.87 & 0.0631 & 1.34 & 1.34 & 2.37 & 0.1675 & 10.87 & 10.87 & 3.22 & 0.1159 \\
\hline 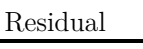 & 7 & 7.48 & 1.07 & & & 0.54 & 0.077 & & & 30.54 & 4.36 & & & 23.64 & 3.38 & & \\
\hline Lack of fit & 3 & 0.45 & 0.15 & 0.085 & 0.9649 & 0.16 & 0.053 & 0.56 & 0.6716 & 24.89 & 8.30 & 5.88 & 0.060 & 18.92 & 6.31 & 5.35 & 0.0695 \\
\hline Pure Error & 4 & 7.04 & 1.76 & & & 0.38 & 0.095 & & & 5.65 & 1.41 & & & 4.72 & 1.18 & & \\
\hline Cor Total & 12 & 25.00 & & & & 1.42 & & & & 69.43 & & & & 55.30 & & & \\
\hline
\end{tabular}

* indicates significant at $5 \%$ level of significance.

\subsection{Optimization of Chemical Pretreatments Prior to Osmotic Dehydration of Onion Slices}

Optimization of chemical pretreatments prior to osmotic dehydration for maximum water loss and minimum solid gain was done based on analysis of various parameters and statistical data. The suitable $\mathrm{CaCl} 2$ and KMS concentration was calculated by software through actual experimental results obtained and statistical analysis. Numerical optimization found a point that maximizes the desirability function.

From the numerical optimization, 5 solutions were found out of which the best combination having desirability of 0.796 was selected. The chemical pretreatment prior to osmotic dehydration of Talaja Red 
onion slices should be carried out $3.00 \% \mathrm{CaCl} 2$ and $0.15 \% \mathrm{KMS}$ concentration. This optimum set of parameters gave the predicted values of osmotic dehydration characteristics i.e. solid gain 5.19\%, water loss of $42.30 \%$, weight loss of $39.44 \%$, and moisture content of $50.68 \%$. This showed that increase in $\mathrm{CaCl} 2$ concentration and decrease in KMS concentration resulted best parameters. The optimum values for different variables and their predicted responses thus obtained are given in Table 5.

Table 5. Optimized variables and their responses for chemical pretreatments prior to osmotic dehydration of Talaja Red onion slices

\begin{tabular}{l|l|l|l}
\hline Variable & Optimized values & Responses & Predicted values \\
\hline \multirow{2}{*}{ CaCl2 concentration, \% } & \multirow{2}{*}{3.00} & Water loss, \% & 42.30 \\
\cline { 3 - 4 } & & Solid gain, \% & 5.19 \\
\hline \multirow{2}{*}{ KMS concentration, \% } & \multirow{2}{*}{0.15} & Weight loss, \% & 39.44 \\
\cline { 3 - 4 } & & Moisture content, \% & 50.68 \\
\hline
\end{tabular}

Lewicki et al. [18] investigated the effect of osmose and calcium chloride as pre-treatments in drying of tomato [18]. Pre-treatment with $\mathrm{CaCl} 2$ increased by $20 \%$ the amount of water removed during osmotic dehydration and facilitated infiltration of sucrose. Treatment with $\mathrm{CaCl} 2$ followed by osmotic dewatering was more effective than osmotic treatment done in the presence of calcium chloride. They concluded calcium chloride increased the rates of convective drying and osmotic dewatering as well.

\section{Conclusion}

It can be concluded that $\mathrm{CaCl} 2$ concentration had significant effect at $5 \%$ level of significance on water loss while all the other linear, interaction and quadratic effects of $\mathrm{CaCl} 2$ and KMS were found to be non-significant on water loss, solid gain, mass loss and moisture content. The maximum water loss i.e. $43.07 \%$ was found in treatment having the combination of $3.00 \% \mathrm{CaCl} 2$ and $0.20 \% \mathrm{KMS}$, while the minimum water loss i.e. $38.88 \%$ was found in treatment having the combination of $1.00 \% \mathrm{CaCl} 2$ and $0.20 \%$ KMS. The chemical pretreatments prior to osmotic dehydration of Talaja red onion slices should be carried out $3.00 \% \mathrm{CaCl} 2$ and $0.15 \% \mathrm{KMS}$.

\section{References}

1. Ade-omowaye BIO, Talens P, Angersbuch A and Knorr D (2003) Kinetics of osmotic dehydration of red bell pepper as influenced by pulse electric field pretreatment. Food Res. Int. 36, 475-482.

2. Anonymous (2014) Hand Book on Horticulture Statistics. Government of India Ministry of Agriculture Department of Agriculture and Cooperation. New Delhi.

3. BARI (2003) Annual Report of Spices Research Centre, Bangladesh Agricultural Research Institute Gazipur, pp. $75-75$.

4. Bas D and Boyaci I (2007) Modelling and optimization I: Usability of response surface methodology, Journal of Food Engineering. 78(3):836-845.

5. BEE (2004) Bureau of Energy Efficiency (BEE) (2004) Best practice manual: dryers. New Delhi, India. https://www.scribd.com/doc/40095998/Best-Practice-Manual-Dryers.pdf Accessed 06 April 2015.

6. Chiralt A and Talens P (2005) Physical and chemical changes induced by osmotic dehydration in plant tissues. Journal of Food Engineering 67: 167-177.

7. Das H (2005) Handbook of Food Processing Operations Analysis. Asian Books Private Limited. New Delhi.

8. Davoodi MG, P Vijayanand, SG Kulkarni, KVR Ramana (2007) Effect of different pre-treatments and dehydration methods on quality characteristics and storage stability of tomato powder. LWT (40): 1832-1840.

9. Dermesonlouoglou EK, Giannakourou MC, Bakalis S and Taoukis PS (2005) Mass transport properties of watermelon tissue in osmotic solutions and effect of osmotic dehydration on frozen watermelon quality. Acta Horticulture 674: 481-487. 
10.Doymaz I (2004) Pretreatment effect on sun drying of mulberry fruits (Morus alba L). Journal of Food Engineering. 65, 205-209.

11.Gazenfer E and Sefa T (2006) Colour retention of red peppers by chemical pretreatment during greenhouse and open sun drying. Journal of Food Engineering, 76, 446-452.

12.Grewal MK, SN Jha, RT Patil, AS Dhatt, Amandeep Kaur, P Jaiswal (2015) J Food Sci Technol. 52(2):11311137.

13.Hough G, Chirife J and Marini C (1993) A simple model for osmotic dehydration of apples. LebensmittelWissenschaft und-Technolgie 26:151-156.

14.http://nhb.gov.in/area\%20_production.html website visited on 01/04/2015

15.http://www.medicalnewstoday.com/articles/276714.php website visited on 1/4/2015

16.Jayaraman KS and Gupta DKD (2006) Drying of fruits and vegetables. In Mujumdar, A. S. (Ed.), Handbook of Industrial Drying (third edition). Pp. 606-634. UK: Taylor \& Francis.

17.Lenart A and Lewicki PP (1988) Osmotic preconcentration of carrot tissue followed by convective drying, preconcentration and drying of food materials, ed. S. Bruin, Elsevier Science, Amsterdam, 307-308.

18.Lewicki PP, Pawlak RP (2005) Effect of osmotic dewatering on apple tissue structure. J Food Eng 66:43-50.

19.Li H and Ramaswamy H (2006) Osmotic dehydration of apple cylinders: I. Conventional batch processing conditions. Drying Technology 24(5):619-630.

20. Mandala IG, Anagnostaras EF, Oikonomou CK (2005) Influence of osmotic dehydration conditions on apple air drying kinetics and their quality characterstics. J Food Eng 69:307-316.

21.Masanet E, Worrell E, Graus W, Galitsky C (2008) Energy efficiency improvement and cost saving opportunities for the fruit and vegetable processing industry: an ENERGY STAR® guide for energy and plant managers. Environmental Energy Technologies Division, University of California, Berkeley.

22.Meyers R and Montogometry DC (1995) Response Surface Methodology. John Wiley and Sons, New York, USA.

23.Mozumder NHMR, Rahman MA, Kamal MS, Mustafa AKM and Rahman MS (2012) Effect of pre-drying chemical treatments on quality of cabinet dryied tomato powder. J. Environ. Sci. \& Natural Reseources. $5(1): 253-265$.

24.Phissut N, Rattanawedee M and Aekkasak K (2013) Effect of osmotic dehydration process on the physical, chemical and sensory properties of osmo-dried cantaloupe. International Food Research Journal 20(1):189-196.

25.Piga A, Pina I, Ozer KB, Agabbio M and Aksoy U (2004) Hot air dehydration of figs (Ficus caracal L.): Drying Kinetics and quality loss. Int. Journal of Food Sci. Technolo., 39, 793-799.

26.Rane DA (2014) Studies on osmotic dehydration of Talaja Red onion. An M. Tech. unpublished thesis. Junagadh Agricultural University, Junagadh.

27.Salvatori D, Andres A, Albors A, Chiralt A, Fito P (1998). Structural and compositional profiles in osmotically dehydrated apple. J. Food Sci. 63: 606-610.

28.Senadeera W, Bhandari B, Young G, and Wijesinghe B (2000) Physical property changes of fruits and vegetable during hor air drying. In A.S. Mujumdar (Ed.), Drying technology in agriculture and food sciences (pp. 159-161). United Staes: science Publishers.

29.Singh U, SK Jain, A Doshi, KH Jain and KV Chahar (2008) Effects of Pretreatments on Drying Characteristics of Button Mushroom. International Journal of Food Engineering, Volume 4, Issue 4. The Berkeley Electronic Press.

30.Sodhi NS and Komal NS (2006) Osmotic dehydration kinetics of carrots. Journal of Food Science and Technology 43(4): 374-376.

31.Spiazzi E, Mascheroni R (1997) Mass transfer model for osmotic dehydration of fruits and vegetables. I. Development of simulation model. J. Food Eng. 34: 387-410.

32. Tharrington ED, Kendall PA and Sofos JN (2005) Inactivation of Escherichia coli 157:H7 during storage or drying of apple slices pretreated with acidic solutions. Int. Journal Food Microbiol. 99, 79-89.

33. Torreggiani D, Bertolo G (2001) Osmotic pre-treatments in fruit processing: chemical, physical and structural effects. J. Food Eng. 49: 247-253.

34.Tunde-Akintunde TY (2010) Effect of pretreatment on drying time and quality of Chilli pepper. Journal of Food Procesing and Preservation. Vol. 34, Issue 4: pp 595-608. DOI:10.1111/j.1745-4549.2010.00360.x. 
35.Xiao HW, H Lin, XD Yao, ZL Du, Z Lou, ZJ Gao (2009) Effects of different pretreatment on drying Kinetics and Quality of sweet potatoes bar undergoing air impingement drying. International Journal of Food Engineering. Vol. 5. Issue 5, Article 5.

36.Yadav AK and SV Singh (2014) Osmotic dehydration of fruits and vegetables: a review. J Food Sci Technol. 51(9):1654-1673. 